\title{
Low concentrations of serum 25-hydroxyvitamin D associated with increased risk for chronic bronchitis among US adults
}

\author{
Guixiang Zhao ${ }^{1 *}$, Earl S. Ford ${ }^{1}$, James Tsai ${ }^{1}$, Chaoyang $\mathrm{Li}^{2}$ and Janet B. Croft ${ }^{1}$ \\ ${ }^{1}$ Division of Adult and Community Health, National Center for Chronic Disease Prevention and Health Promotion, Centers \\ for Disease Control and Prevention, 4770 Buford Highway, Mailstop K67, Atlanta, GA 30341, USA \\ ${ }^{2}$ Division of Behavioral Surveillance, Public Health Surveillance Program Office, Office of Surveillance, Epidemiology and \\ Laboratory Services, Centers for Disease Control and Prevention, Atlanta, GA, USA
}

(Submitted 26 March 2011 - Final revision received 18 June 2011 - Accepted 4 July 2011 - First published online 8 September 2011)

\begin{abstract}
Increasing evidence suggests that vitamin D benefits both innate and adaptive immunity, thereby eliciting an anti-inflammatory effect and reducing the risk of infectious disease. The present study examined the association between serum 25-hydroxyvitamin D (25(OH)D) levels and the risk of chronic bronchitis among US adults. We analysed data from 6872 US adults aged $\geq 20$ years who participated in the $2003-6$ National Health and Nutrition Examination Survey. Prevalence and OR with 95\% CI of having self-reported chronic bronchitis were estimated by quintiles of $25(\mathrm{OH}) \mathrm{D}$ or vitamin D-deficiency status after adjustment for potential confounders. The results showed that the adjusted prevalence of chronic bronchitis ranged from $2.4(95 \%$ CI 1.4, 3.3) \% among adults in the highest quintile of $25(\mathrm{OH}) \mathrm{D}$ $(\geq 30 \mathrm{ng} / \mathrm{ml})$ to $4 \cdot 1(95 \%$ CI $2 \cdot 5,5 \cdot 6) \%$ among adults in the lowest quintile $(<15 \mathrm{ng} / \mathrm{ml} ; P$ for trend $<0 \cdot 01)$. The adjusted OR for chronic bronchitis was $1.85(95 \% \mathrm{CI} 1 \cdot 06,3 \cdot 24)$ in adults with $<15 \mathrm{ng} / \mathrm{ml} 25(\mathrm{OH}) \mathrm{D}$ and $1.77(95 \% \mathrm{CI} 1 \cdot 19,2 \cdot 65)$ in those with 15 to $<20 \mathrm{ng} / \mathrm{ml}$ $25(\mathrm{OH}) \mathrm{D}$ compared with adults with $\geq 30 \mathrm{ng} / \mathrm{ml} 25(\mathrm{OH}) \mathrm{D}$. Additionally, the adjusted OR for chronic bronchitis was $1.52(95 \% \mathrm{CI} 1.03$, $2 \cdot 26)$ among adults with vitamin D deficiency $(<20 \mathrm{ng} / \mathrm{ml} 25(\mathrm{OH}) \mathrm{D})$ compared with those with $\geq 20 \mathrm{ng} / \mathrm{ml} 25(\mathrm{OH}) \mathrm{D}$. For every $1 \mathrm{ng} / \mathrm{ml}$ increase in $25(\mathrm{OH}) \mathrm{D}$, the likelihood of having chronic bronchitis fell by $2.6 \%(P=0 \cdot 016)$. In conclusion, low serum $25(\mathrm{OH}) \mathrm{D}$ levels are associated with the increased risk of chronic bronchitis among US adults. The present results provide support for continuing research on the role of vitamin $\mathrm{D}$ in lung diseases.
\end{abstract}

Key words: Vitamin D: 25-Hydroxyvitamin D: Chronic bronchitis: National Health and Nutrition Examination Survey

Chronic bronchitis is a disorder characterised by chronic mucus hypersecretion, with clinical symptoms presented as productive cough and phlegm that last at least 3 months every year for at least 2 years ${ }^{(1)}$. The underlying pathophysiology of chronic bronchitis is inflammation and swelling of the epithelium of the bronchi, which results in the increased risk of lung infections by viral, bacterial and atypical organisms ${ }^{(1)}$. This causes recurrent episodes of acute exacerbations of chronic bronchitis ${ }^{(2)}$, which often leads to a decline in lung function $^{(3,4)}$, poor quality of life ${ }^{(5)}$, increased risk of chronic obstructive pulmonary disease (COPD - obstruction of the respiratory airways, especially with mucus) and death ${ }^{(6)}$, and a significant economic burden on the health care system and society due to direct costs of hospitalisations ${ }^{(3,4,7)}$.

Vitamin D has received increased attention for its influence on non-skeletal medical conditions, apart from its well-known function in the regulation of $\mathrm{Ca}$ and phosphate homeostasis in bone metabolism. Although vitamin $\mathrm{D}$ is hydroxylated to 25-hydroxyvitamin D (25(OH)D) and then 1,25-dihydroxyvitamin $\mathrm{D}\left(1,25(\mathrm{OH})_{2} \mathrm{D}\right)$ in the liver and kidneys, respectively, it can also be metabolised by the cells of the immune system $^{(8-10)}$. In addition, vitamin $\mathrm{D}$ receptors are widely expressed in immune cells ${ }^{(11)}$, and vitamin D-binding protein also has immunomodulatory functions relating to macrophage activation and neutrophil chemotaxis in the lung ${ }^{(12)}$. Thus, the vitamin D axis plays an important role in respiratory health by inhibiting pulmonary inflammatory responses and enhancing the innate antimicrobial response against respiratory pathogens ${ }^{(13,14)}$. Consequently, a low $25(\mathrm{OH}) \mathrm{D}$ level or vitamin D deficiency has been associated with the increased risk of upper-respiratory-tract infections ${ }^{(15)}$ and decreased pulmonary function ${ }^{(16-19)}$, and linked to wheezing illness and asthma exacerbation in both children and adults ${ }^{(20,21)}$, although other studies have reported that

Abbreviations: $1,25(\mathrm{OH})_{2} \mathrm{D}, 1,25$-dihydroxyvitamin $\mathrm{D} ; 25(\mathrm{OH}) \mathrm{D}, 25$-hydroxyvitamin D; COPD, chronic obstructive pulmonary disease; MET, metabolic equivalent; NHANES, National Health and Nutrition Examination Survey.

* Corresponding author: Dr G. Zhao, fax +1 770488 8150, email fwj4@cdc.gov 
serum concentrations of $25(\mathrm{OH}) \mathrm{D}$ were not associated with lung function ${ }^{(22,23)}$. In the present study, we used data from a large, nationally representative survey sample to examine (1) the prevalence of self-reported, physician-diagnosed chronic bronchitis among US adults and (2) the extent to which chronic bronchitis is independently associated with varying concentrations of serum $25(\mathrm{OH}) \mathrm{D}$ while controlling for potential confounders.

\section{Methods \\ Study design}

We analysed data from the 2003-6 National Health and Nutrition Examination Survey (NHANES), which uses a multistage stratified sampling design to collect data from a nationally representative sample of the non-institutionalised civilian US population on a 2-year cycle basis. A more detailed description of the NHANES design and methods has been reported elsewhere $^{(24)}$. Survey participants were initially interviewed at home and then invited to a mobile examination centre, where they received various examinations and provided blood samples for laboratory tests. The present study was conducted according to the guidelines laid down in the Declaration of Helsinki. All procedures involving human subjects were approved by the Research Ethics Review Board of the National Center for Health Statistics, Centers for Disease Control and Prevention. Written informed consent was obtained from all participants.

\section{Participants and measurements}

We examined interview and laboratory data from participants aged 20 years or older. Participants' chronic bronchitis (yes, no) was assessed by asking them whether they had ever been told by a doctor or other health professional that they had this condition and still had it during the survey. Selfreported information about chronic respiratory disease has shown to have good or very good agreement with that from general practice medical records ${ }^{(25)}$.

Participants' serum specimens were collected during the medical examination and were frozen and stored at less than $-70^{\circ} \mathrm{C}$ until analysis. Serum concentrations of $25(\mathrm{OH}) \mathrm{D}$ were measured in accordance with the DiaSorin RIA procedure (DiaSorin 25(OH)D ${ }^{125}$ I RIA kit; DiaSorin Corporation, Stillwater, MN, USA), which has been described in detail in laboratory procedure manuals that can be accessed at the NHANES website ${ }^{(24)}$. Sensitivity for the assay was $1.5 \mathrm{ng} / \mathrm{ml}$, and the CV ranged from $8.9 \%$ for the NHANES 2003-4 participants to $9 \cdot 9 \%$ for the NHANES $2005-6$ participants.

The demographic covariates in the present analyses were participants' age (20-39, 40-59 and $\geq 60$ years), sex, race/ethnicity (non-Hispanic white, non-Hispanic black, Mexican American and other), education (below high school graduate, high school graduate/equivalent and above high school diploma) and family poverty:income ratio (calculated as a ratio of family income:poverty threshold and categorised as $<1 \cdot 0,1 \cdot 0$ to $<3 \cdot 0$ and $\geq 3 \cdot 0$ ). Lifestyle-related behaviours included BMI $\left(<25 \cdot 0,25 \cdot 0-29 \cdot 9\right.$ and $\geq 30 \cdot 0 \mathrm{~kg} / \mathrm{m}^{2}$, calculated from measured weight and height), smoking (current, former and non-smoking), physical activity (yes, no), excessive alcohol drinking (yes, no) and dietary supplement use (yes, no). Current smoking was defined as having smoked at least 100 cigarettes in one's life and still smoking, former smoking as having smoked at least 100 cigarettes in one's life but stopped and non-smoking as having smoked fewer than 100 cigarettes in one's life. Participants' physical activity was assessed by asking participants whether, over the past $30 \mathrm{~d}$, (1) they had engaged in specific moderate or vigorous leisure-time activities, (2) they had walked or bicycled as part of getting to and from work, or school, or to do errands (transportation physical activity) and (3) they had done any tasks in or around their home or yard for at least $10 \mathrm{~min}$ that required moderate or greater physical effort (household physical activity). If a confirmative answer of 'yes' was recorded, they were then asked about how many times and the average duration each time they engaged in the activities over the past $30 \mathrm{~d}$. Based on the metabolic equivalent (MET) score for specific activities, we calculated the average MET-h/week that summed leisure-time, transportation and household physical activity. Participants with a MET-h/week of $>0$ were considered physically active and those with a MET-h/ week of 0 were considered inactive. Alcohol consumption was calculated as the average number of daily drinks. Excessive alcohol drinking was defined as having $>2$ drinks/d in men and $>1 \mathrm{drink} / \mathrm{d}$ in women during the previous 12 months. Dietary supplement use was assessed by asking participants whether they had taken any vitamins, minerals or other dietary supplements during the previous month. Covariates on medical conditions included serum concentrations of total cholesterol ( $<2000 \mathrm{mg} / 1, \geq 2000 \mathrm{mg} / \mathrm{ml}$ ), serum concentrations of C-reactive proteins $(<3.0 \mathrm{mg} / \mathrm{l}, \geq 3.0 \mathrm{mg} / \mathrm{l})$, systolic blood pressure $(<140 \mathrm{mmHg}, \geq 140 \mathrm{mmHg})$, physician-diagnosed diabetes (yes, no), physician-diagnosed heart disease including coronary artery disease, angina pectoris and myocardial infarction (yes, no), and current physician-diagnosed asthma (yes, no). Serum concentrations of total cholesterol were measured enzymatically on a Hitachi 717 and 912 (Hitachi Global Storage Technologies, San Jose, CA, USA. Serum concentrations of C-reactive protein were measured by latex-enhanced nephelometry on a Behring Nephelometer (Dade Behring Diagnostics Inc., Somerville, NJ, USA). Mean systolic blood pressure was calculated as the average of the last two readings for participants who had three measurements, as the last reading for those who had two measurements and as the only reading for those who had one measurement. Health insurance status was assessed by asking participants whether they were covered by health insurance or some other kind of health care plan including those obtained through employment or purchased directly as well as government programmes such as Medicare and Medicaid that provide medical care or help pay medical bills (yes, no). Times of health care visit were assessed by asking participants how many times, during the past 12 months, they had seen a doctor or other health care professional about their health at a doctor's office, a clinic, hospital 
emergency room, at home or some other place (categorised as $0,1-3$ and $\geq 4$ times). The period of blood sampling was used as a surrogate of potential sun exposure, which was assessed based on the 6-month time period when survey participants' examination was performed; we considered those examined 1 November to 30 April as having low sun exposure and those examined 1 May to 31 October as having high sun exposure.

\section{Statistical analysis}

The prevalence with $95 \% \mathrm{CI}$ of chronic bronchitis by quintiles of $25(\mathrm{OH}) \mathrm{D}$ and by categorical covariates was estimated using the sampling weights and age-adjusted to the 2000 US population. Adjusted prevalence, OR and 95\% CI for having chronic bronchitis were estimated by conducting logistic regression using serum $25(\mathrm{OH}) \mathrm{D}$ concentrations (either by quintile or as a continuous variable) as the independent variable while controlling for covariates including sociodemographic characteristics, lifestyle-related behaviours, access to health care, chronic medical conditions and period of blood sampling. Tests for linear trends on the OR across quintiles of $25(\mathrm{OH}) \mathrm{D}$ were conducted using the median values for each quintile in logistic regression models. In all analyses, we used SUDAAN (Software for the Statistical Analysis of Correlated Data, Release 9.0; Research Triangle Institute, Research Triangle Park, NC, USA) to account for the complex sampling design.

\section{Results}

Of the 9515 survey participants aged $\geq 20$ years who attended the mobile examination centre, we excluded 544 women who reported they were pregnant, as well as thirty-eight participants whose chronic bronchitis status was unknown, and 522 participants whose serum $25(\mathrm{OH}) \mathrm{D}$ concentrations were not measured. After further excluding those who had missing values for covariates, 6872 (77\%) eligible participants remained in the present analyses. The mean age of eligible study participants was 46.2 years; $74.0 \%$ were non-Hispanic white, $10 \cdot 3 \%$ non-Hispanic black, $7 \cdot 7 \%$ Mexican American and $8.0 \%$ of 'other' race/ethnicity. About $57 \cdot 1 \%$ attained an educational level above a high school diploma and 52.3\% had a poverty:income ratio of $\geq 3$.

Overall, the unadjusted prevalence of chronic bronchitis was $3.2(95 \%$ CI $2 \cdot 7,3 \cdot 8) \%$ and the age-adjusted prevalence was $3 \cdot 1$ (95\% CI $2 \cdot 6,3 \cdot 7) \%$. The prevalence estimates differed significantly by all sociodemographic characteristics except for education, by smoking and physical activity status, by times of health care visit and by some co-existing medical conditions (Table 1). Notably, the prevalence of chronic bronchitis increased significantly with increasing age $(P<0.001)$ but decreased with increasing poverty:income ratio $(P<0.05)$; the prevalence was lower among men than among women $(P<0.01)$; lower among Hispanics than among members of other racial/ethnic groups $(P<0 \cdot 05)$; but higher among current smokers than among former- and non-smokers $(P<0 \cdot 05)$; higher among those who were physically inactive than among those who were active $(P<0 \cdot 01)$; higher among those who had $\geq 4$ times of health care visit than among those who had $\leq 3$ times of health care visit in the previous 12 months $(P<0 \cdot 001)$; and higher among those with elevated C-reactive protein levels $(P<0 \cdot 001)$, diabetes $(P<0.05)$, heart disease $(P<0.01)$ and current asthma $(P<0.001)$ than among their respective counterparts (Table 1 ).

The age-adjusted prevalence of chronic bronchitis increased linearly from $2 \cdot 2(95 \%$ CI $1.4,3.5) \%$ among adults in the highest $25(\mathrm{OH}) \mathrm{D}$ quintile $(\geq 30 \mathrm{ng} / \mathrm{ml})$ to $4.6(95 \% \mathrm{CI} 3 \cdot 2,6.5) \%$ among those in the lowest quintile $(<15 \mathrm{ng} / \mathrm{ml} ; P<0.001$ for a linear trend). Conversely, the age-adjusted mean concentration of $25(\mathrm{OH}) \mathrm{D}$ among adults with chronic bronchitis $(20.6 \mathrm{ng} / \mathrm{ml}, 95 \%$ CI $18 \cdot 7,22 \cdot 5 \mathrm{ng} / \mathrm{ml})$ was significantly lower than that among adults without chronic bronchitis $(23.4 \mathrm{ng} / \mathrm{ml}$, $95 \%$ CI $22.6,24.3 \mathrm{ng} / \mathrm{ml}, P<0.001)$, which represented a $13.6 \%$ relative difference between the two groups.

After multivariate adjustment for sociodemographic characteristics, lifestyle-related behaviours, access to health care, chronic medical conditions and period of blood sampling, the inverse trend in the prevalence of chronic bronchitis by quintile of $25(\mathrm{OH}) \mathrm{D}$ remained statistically significant ( $P=0.013$; Table 2). The adjusted OR for chronic bronchitis was 1.85 (95\% CI 1.06, 3.24) among adults with 25(OH)D concentrations of $<15 \mathrm{ng} / \mathrm{ml}$ and 1.77 (95\% CI 1.19, 2.65) among those with $25(\mathrm{OH}) \mathrm{D}$ concentrations of 15 to $<20 \mathrm{ng} / \mathrm{ml}$, compared with adults with $25(\mathrm{OH}) \mathrm{D}$ concentrations of $\geq 30 \mathrm{ng} / \mathrm{ml}$. For every $1 \mathrm{ng} / \mathrm{ml}$ increase in $25(\mathrm{OH}) \mathrm{D}$, the odds of having chronic bronchitis fell by $2 \cdot 6 \%(P=0 \cdot 016$; Table 2$)$.

Alternatively, we conducted sub-analysis by dichotomising participants as having $(25(\mathrm{OH}) \mathrm{D}<20 \mathrm{ng} / \mathrm{ml})$ and not having $(25(\mathrm{OH}) \mathrm{D} \geq 20 \mathrm{ng} / \mathrm{ml})$ vitamin $\mathrm{D}$ deficiency. The adjusted prevalence of having chronic bronchitis among adults with vitamin D deficiency was significantly higher than among those without vitamin D deficiency (3.9\%, 95\% CI $2.9,5.0 \%$ v. $2 \cdot 7 \%, 95 \%$ CI $2 \cdot 2,3 \cdot 2, P=0 \cdot 035$; adjusted OR $1 \cdot 52,95 \% \mathrm{CI}$ $1 \cdot 03,2 \cdot 26)$.

\section{Discussion}

The present analyses of data from a large, nationally representative survey demonstrated a significant inverse relationship between serum $25(\mathrm{OH}) \mathrm{D}$ levels and the risk of chronic bronchitis among adults of the USA. We found that adults with vitamin D deficiency (defined as $25(\mathrm{OH}) \mathrm{D}<20 \mathrm{ng} / \mathrm{ml}$ based on a commonly used cut-point ${ }^{(26)}$ ) were $52 \%$ more likely to have chronic bronchitis than those with $25(\mathrm{OH}) \mathrm{D} \geq 20 \mathrm{ng} / \mathrm{ml}$, and $77-85 \%$ were more likely to have the condition than those with $25(\mathrm{OH}) \mathrm{D} \geq 30 \mathrm{ng} / \mathrm{ml}$. A significant dose-response relationship was present.

The majority of previous studies have shown that low $25(\mathrm{OH}) \mathrm{D}$ levels are associated with a higher risk of $\operatorname{COPD}^{(27,28)}$ - a major respiratory health condition constituting the third leading cause of death in 2008 in the USA ${ }^{(29)}$. However, evidence has shown that the prevalence or the 30-year cumulative incidence of chronic bronchitis was significantly higher than that of COPD in middle-aged Finnish men (42v. $32 \%$ in continuous smokers, $26 v$. 14\% in former smokers 
Table 1. Prevalence* of chronic bronchitis among US adults aged $\geq 20$ years by selected characteristics, National Health and Nutrition Examination Survey 2003-6

(Numbers, percentages and $95 \%$ confidence intervals)

\begin{tabular}{|c|c|c|c|c|}
\hline Characteristics & $n$ & $\%$ & $95 \% \mathrm{Cl}$ & $P \dagger$ \\
\hline \multicolumn{5}{|l|}{ Overall } \\
\hline Unadjusted & 6872 & $3 \cdot 19$ & $2 \cdot 67,3 \cdot 82$ & \\
\hline Age-adjusted & 6872 & $3 \cdot 11$ & $2.59,3.72$ & \\
\hline \multicolumn{5}{|l|}{ Sociodemographic } \\
\hline Age (years) & & & & $<0.001$ \\
\hline $20-39$ & 2190 & 1.79 & $1 \cdot 26,2.53$ & \\
\hline $40-59$ & 2194 & 3.85 & $3.01,4.91$ & \\
\hline$\geq 60$ & 2488 & $4 \cdot 20$ & $3 \cdot 31,5 \cdot 33$ & \\
\hline \multicolumn{4}{|l|}{ Sex } & 0.004 \\
\hline Men & 3583 & $2 \cdot 11$ & $1.57,2 \cdot 84$ & \\
\hline Women & 3289 & 4.09 & $3 \cdot 19,5 \cdot 23$ & \\
\hline \multicolumn{4}{|l|}{ Race/ethnicity } & $<0.001$ \\
\hline Non-Hispanic white & 3687 & $3 \cdot 30$ & $2 \cdot 74,3.96$ & \\
\hline Non-Hispanic black & 1395 & 3.09 & $2.06,4.62$ & \\
\hline Mexican American & 1348 & 0.96 & $0.59,1.58$ & \\
\hline Other & 442 & 3.29 & $1 \cdot 83,5 \cdot 86$ & \\
\hline \multicolumn{4}{|l|}{ Education } & 0.197 \\
\hline Below high school graduate & 1886 & 4.28 & $2 \cdot 65,6 \cdot 84$ & \\
\hline High school graduate & 1688 & $3 \cdot 19$ & $2 \cdot 30,4 \cdot 41$ & \\
\hline Above high school diploma & 3298 & $2 \cdot 81$ & $2 \cdot 27,3.47$ & \\
\hline \multicolumn{4}{|l|}{ Poverty:income ratio } & 0.030 \\
\hline$<1 \cdot 0$ & 1147 & 5.48 & $3.83,7.78$ & \\
\hline $1.0-2.9$ & 2909 & 3.45 & $2.39,4.96$ & \\
\hline$\geq 3.0$ & 2816 & 2.45 & $1.91,3.13$ & \\
\hline \multicolumn{5}{|l|}{ Lifestyle-related behaviours } \\
\hline BMl $\left(\mathrm{kg} / \mathrm{m}^{2}\right)$ & & & & 0.282 \\
\hline$<25.0$ & 2045 & 2.93 & $2 \cdot 14,4 \cdot 00$ & \\
\hline $25 \cdot 0-29 \cdot 9$ & 2452 & 2.83 & $1.99,4.02$ & \\
\hline \multirow{2}{*}{\multicolumn{4}{|c|}{ Smoking }} & \\
\hline & & & & $<0.001$ \\
\hline Current smoker & 1584 & $5 \cdot 76$ & $4.44,7.46$ & \\
\hline Former smoker & 1865 & 3.01 & $2.03,4.44$ & \\
\hline Never smoked & 3423 & $2 \cdot 10$ & $1 \cdot 53,2 \cdot 88$ & \\
\hline \multicolumn{4}{|l|}{ Physical activity } & 0.003 \\
\hline Yes & 4161 & $2 \cdot 52$ & $2 \cdot 05,3 \cdot 11$ & \\
\hline No & 2711 & $4 \cdot 24$ & $3.24,5.52$ & \\
\hline \multicolumn{4}{|l|}{ Excessive alcohol drinking } & 0.765 \\
\hline Yes & 509 & 2.73 & $1 \cdot 70,4 \cdot 37$ & \\
\hline No & 6363 & $3 \cdot 11$ & $2.60,3.72$ & \\
\hline \multicolumn{4}{|l|}{ Dietary supplement use } & 0.441 \\
\hline Yes & 3503 & $3 \cdot 11$ & $2.48,3.90$ & \\
\hline No & 3369 & $3 \cdot 21$ & $2 \cdot 43,4.23$ & \\
\hline Access to health care & & & & \\
\hline Health insurance & & & & 0.524 \\
\hline Yes & 5471 & 2.94 & $2 \cdot 41,3.57$ & \\
\hline No & 1401 & 3.89 & $2 \cdot 79,5 \cdot 41$ & \\
\hline Times of health care visit & & & & $<0.001$ \\
\hline 0 & 1090 & 1.35 & $0.71,2.54$ & \\
\hline $1-3$ & 3016 & 1.75 & $1.23,2.47$ & \\
\hline$\geq 4$ & 2766 & 5.42 & $4 \cdot 33,6 \cdot 77$ & \\
\hline Clinical measurements and medical conditions & & & & \\
\hline Systolic blood pressure (mmHg) & & & & 0.373 \\
\hline$\geq 140$ & 1371 & 3.63 & $1 \cdot 92,6 \cdot 77$ & \\
\hline$<140$ & 5501 & $3 \cdot 13$ & $2.45,3.99$ & \\
\hline Serum total cholesterol (mg/l) & & & & 0.105 \\
\hline$\geq 2000$ & 3902 & 3.32 & $2 \cdot 58,4 \cdot 28$ & \\
\hline$<2000$ & 2970 & $2 \cdot 94$ & $2.33,3.69$ & \\
\hline Serum C-reactive protein $(\mathrm{mg} / \mathrm{l})$ & & & & $<0.001$ \\
\hline $\begin{array}{l}\geq 0.3 \\
<0.3\end{array}$ & 2721 & 4.38 & $3.46,5 \cdot 53$ & \\
\hline $\begin{array}{r}<0.3 \\
\text { Diabetes }\end{array}$ & 4151 & $2 \cdot 31$ & $1 \cdot 76,3 \cdot 02$ & 0.022 \\
\hline Yes & 731 & 5.88 & $2.92,11.48$ & \\
\hline No & 6141 & 2.92 & $2.40,3.55$ & \\
\hline CHD & & & & 0.002 \\
\hline Yes & 596 & 11.84 & $6 \cdot 34,21 \cdot 05$ & \\
\hline No & 6276 & $2 \cdot 79$ & $2 \cdot 27,3 \cdot 43$ & \\
\hline Current asthma & & & & $<0.001$ \\
\hline Yes & 509 & $16 \cdot 58$ & $12 \cdot 71,21 \cdot 34$ & \\
\hline No & 6363 & 1.98 & $1.59,2.46$ & \\
\hline Period of blood sampling & & & & 0.188 \\
\hline May-October & 3122 & $3 \cdot 68$ & $2 \cdot 81,4 \cdot 80$ & \\
\hline November-April & 3750 & $2 \cdot 73$ & $2 \cdot 10,3 \cdot 54$ & \\
\hline
\end{tabular}

${ }^{*}$ Reported as age-adjusted except for age-specific prevalence.

$\dagger P$ values from $\chi^{2}$ tests. 
Table 2. Adjusted prevalence and OR with $95 \% \mathrm{Cl}$ for having chronic bronchitis among US adults aged $\geq 20$ years, National Health and Nutrition Examination Survey 2003-6

(Odds ratios and $95 \%$ confidence intervals)

\begin{tabular}{|c|c|c|c|c|c|c|c|c|c|}
\hline \multirow[b]{3}{*}{$25(\mathrm{OH}) \mathrm{D}$} & \multirow[b]{3}{*}{$n$} & \multirow[b]{3}{*}{ Adjusted prevalence (\%)† } & \multirow[b]{3}{*}{$95 \% \mathrm{Cl}$} & \multicolumn{6}{|c|}{ Regression analyses } \\
\hline & & & & \multicolumn{2}{|c|}{ Model $1^{*}$} & \multicolumn{2}{|c|}{ Model 2* } & \multicolumn{2}{|c|}{ Model 3* } \\
\hline & & & & OR & $95 \% \mathrm{Cl}$ & OR & $95 \% \mathrm{Cl}$ & OR & $95 \% \mathrm{Cl}$ \\
\hline \multicolumn{10}{|l|}{ Quintile of $25(\mathrm{OH}) \mathrm{D} \ddagger$} \\
\hline Q1 $(<15 \mathrm{ng} / \mathrm{ml})$ & 1631 & 4.05 & $2.53,5.57$ & $2 \cdot 16$ & $1.26,3.71$ & 1.88 & $1.16,3.05$ & 1.85 & $1.06,3.24$ \\
\hline Q2 (15-<20 ng/ml) & 1373 & 3.91 & $2 \cdot 63,5 \cdot 18$ & 1.82 & $1 \cdot 16,2 \cdot 87$ & 1.74 & $1 \cdot 19,2.55$ & 1.77 & $1 \cdot 19,2 \cdot 65$ \\
\hline Q3 $(20-<25 \mathrm{ng} / \mathrm{ml})$ & 1471 & 3.24 & $2 \cdot 10,4 \cdot 38$ & 1.47 & $0.81,2.66$ & 1.49 & $0.84,2.66$ & 1.42 & $0.72,2.82$ \\
\hline Q4 $(25-<30 \mathrm{ng} / \mathrm{ml})$ & 1189 & 2.51 & $1.49,3.54$ & 1.07 & $0.53,2.13$ & 1.08 & $0.55,2.14$ & 1.07 & $0.55,2.07$ \\
\hline Q5 ( $\geq 30 \mathrm{ng} / \mathrm{ml})$ & 1208 & $2 \cdot 37$ & $1.42,3.32$ & 1.00 & Ref & 1.00 & Ref & 1.00 & Ref \\
\hline$P$ for trend & & \multicolumn{2}{|l|}{0.013} & \multicolumn{2}{|c|}{$<0.001$} & \multicolumn{2}{|r|}{0.002} & \multicolumn{2}{|r|}{0.007} \\
\hline Continuous 25(OH)D§ & 6872 & - & - & & \multirow{2}{*}{\multicolumn{2}{|c|}{-0.028}} & \multirow{2}{*}{\multicolumn{2}{|c|}{-0.026}} \\
\hline Regression coefficient & & & & & & & & & \\
\hline SE & & & & \multicolumn{2}{|r|}{0.010} & \multicolumn{2}{|r|}{0.009} & \multicolumn{2}{|r|}{0.010} \\
\hline$P$ for trend & & & & \multicolumn{2}{|r|}{0.003} & \multicolumn{2}{|r|}{0.006} & \multicolumn{2}{|r|}{0.016} \\
\hline
\end{tabular}

25(OH)D, 25-hydroxyvitamin D; Ref, reference.

${ }^{*}$ Model 1, unadjusted; Model 2, adjusted for sociodemographic characteristics (age, sex, race/ethnicity, education and poverty:income ratio), lifestyle-related behaviours (BMI, smoking, excessive alcohol drinking, physical activity and dietary supplement use), serum concentrations of total cholesterol and C-reactive protein, systolic blood pressure and 6-month period of blood sampling; Model 3, adjusted for variables in Model 2 plus access to health care including health insurance and times of health care visit in the past 12 months, and co-morbidities including diabetes, CHD and current asthma.

$\dagger$ Estimated as predicted marginals after adjustment for all covariates listed in Table 1.

$\ddagger$ Quintiles of $25(\mathrm{OH}) \mathrm{D}$ were entered in the logistic regression models.

$\S$ Continuous 25(OH)D concentrations were entered in the regression models.

and $22 v .12 \%$ in those who had never smoked $)^{(1,3)}$. In addition, people with chronic bronchitis, regardless of whether they had airflow obstruction, had reduced lung function, increased risk of all-cause mortality ${ }^{(1,3)}$ and increased risk of cardiovascular mortality ${ }^{(6)}$. Thus, the inverse and dosedependent relationship that we found between serum $25(\mathrm{OH}) \mathrm{D}$ concentrations and the risk of chronic bronchitis potentially has important implications in both clinical practices and public health intervention programmes on respiratory health.

At present, we are not aware of any studies on the association of $25(\mathrm{OH}) \mathrm{D}$ specifically with chronic bronchitis. The present results are consistent with the findings of several other studies that have evaluated the relationships between vitamin D deficiency and the risk of other lung diseases. For example, low 25(OH)D levels have been linked to impaired lung function as shown by lowered forced expiratory volume in $1 \mathrm{~s}$ and forced vital capacity in the general population $^{(16)}$ and in people with chronic bronchitis, asthma and $\operatorname{COPD}^{(3,16,18,30)}$. However, results of a recent study conducted in continuous smokers with mild-to-moderate COPD showed that baseline $25(\mathrm{OH}) \mathrm{D}$ levels were not predictive of the rate of subsequent lung function declining ${ }^{(22)}$. Other research has also implicated vitamin $\mathrm{D}$ in respiratory infections. For example, Ginde et al. $^{(15)}$ reported that low $25(\mathrm{OH}) \mathrm{D}$ concentrations were inversely associated with upper-respiratory-tract infection in the general population and that the association was even stronger among people with respiratory tract diseases such as asthma and COPD. Liu et al. ${ }^{(14,31)}$ further reported that $1,25(\mathrm{OH})_{2} \mathrm{D}_{3}$ at a concentration of $1 / 10^{8} \mathrm{M}$ enhanced human antimicrobial activity against mycobacterium tuberculosis in cultured cells. The present results combined with these previous findings suggest that vitamin D may exert beneficial effects on respiratory health.

Low 25(OH)D levels have also been associated with wheezing and asthma severity in children ${ }^{(20,21)}$. However, evidence concerning the association between asthma or the severity of asthma and serum 25(OH)D concentrations among adults remains controversial ${ }^{(30,32)}$. In the present study, we did not observe a significant association between serum 25(OH)D concentrations and the risk of asthma (data not shown). In fact, the present results demonstrated that the inverse relationship between serum $25(\mathrm{OH}) \mathrm{D}$ concentrations and the risk of chronic bronchitis was independent of asthma status, although chronic bronchitis was highly prevalent in people with asthma. Thus, future studies are needed to further investigate the underlying mechanisms by which vitamin $\mathrm{D}$ may be differentially associated with chronic lung conditions.

An inflammatory component, characterised by the presence of numerous cellular elements such as macrophages and neutrophils and their products - pro-inflammatory cytokines, has been shown to be involved in the pathophysiology of chronic bronchitis, resulting in oxidative stress, protease/antiprotease imbalance and tissue damage. Vitamin $\mathrm{D}$ has been shown to have immunomodulatory effects ${ }^{(9,10,33,34)} \cdot 1-\alpha$-Hydroxylase, a $25(\mathrm{OH}) \mathrm{D}$-activating enzyme, is present not only in the kidney but also in activated macrophages and dendritic cells $^{(35,36)}$. Vitamin D receptors are also expressed in activated inflammatory cells ${ }^{(11)}$. Previous studies ${ }^{(37,38)}$ have shown that $1,25(\mathrm{OH})_{2} \mathrm{D}_{3}$ inhibits T-cell activation and proliferation, thereby altering the cytokine expression profile. Vitamin D has also been shown to activate Toll-like receptors in human macrophages, leading to the induction of the antimicrobial peptide cathelicidin and subsequent killing of intracellular bacteria $^{(14,31)}$. Thus, the immunomodulatory 
effects of vitamin D may serve as one of the mechanisms underlying its beneficial effects on chronic lung diseases.

Although the present study demonstrated that low serum $25(\mathrm{OH}) \mathrm{D}$ levels were associated with an increased likelihood of having chronic bronchitis, a causal relationship cannot be established from the present cross-sectional study design, which is one of the study limitations. As we have discussed earlier, the vitamin D axis may play an important role in respiratory health through immunomodulatory function such as inhibiting pulmonary inflammatory responses and enhancing the innate antimicrobial response against respiratory pathogens $^{(13,14,31,37,38)}$. On the other hand, people with chronic respiratory diseases are at high risks for functional limitations, poor capability in physical functioning, unhealthy behaviours and impaired quality of life ${ }^{(39,40)}$. Consequently, these patients are less likely to go outside for exercise and get sun exposure, thereby at risk of vitamin D deficiency. Thus, it is highly possible that bidirectional associations between low 25(OH)D levels and chronic bronchitis exist in the present study, and the causal relationship deserves further investigation. Second, we are unable to assess pulmonary function in participants who had reported having chronic bronchitis because spirometry was not performed in NHANES 2003-6. Third, although we have included the 6-month period of blood sampling as a surrogate of potential sun exposure, we were unable to adjust for actual seasonality and geographic location due to the lack of data on these variables. Finally, it is unlikely that the variation in serum $25(\mathrm{OH}) \mathrm{D}$ measurements between NHANES 2003-4 and 2005-6 affected the present results in a meaningful way ${ }^{(41)}$.

In conclusion, the present results showed that low serum $25(\mathrm{OH}) \mathrm{D}$ concentrations were associated with an increased likelihood of chronic bronchitis among US adults; those with $25(\mathrm{OH}) \mathrm{D}$ concentrations of $<20 \mathrm{ng} / \mathrm{ml}$ were at almost twice the risk of the condition as those with $25(\mathrm{OH}) \mathrm{D}$ concentrations of $\geq 30 \mathrm{ng} / \mathrm{ml}$. The results add to a growing body of literature on the potential effects of vitamin D on respiratory health and suggest that further research in this area is warranted. Especially, longitudinal studies or vitamin D supplementation trials are needed to further explore whether serum $25(\mathrm{OH}) \mathrm{D}$ concentrations are causally linked to the risk of chronic bronchitis. In the meantime, given the high prevalence of vitamin D deficiency/insufficiency in the USA, especially in the African-American population ${ }^{(26)}$, and the emerging data showing that vitamin D may beneficially affect respiratory health, health care providers should consider alerting their patients with chronic bronchitis about the need for adequate intake of vitamin $\mathrm{D}^{(42)}$ as well as testing the $25(\mathrm{OH}) \mathrm{D}$ concentrations of their patients.

\section{Acknowledgements}

The findings and conclusions in the present study are those of the authors and do not necessarily represent the official position of the Centers for Disease Control and Prevention. The authors' contributions were as follows: G. Z. and E. S. F. had full access to all the data in the study and took responsibility for the integrity of the data and the accuracy of the data analysis. G. Z. obtained the data from NHANES website, performed statistical analyses, interpreted the data and prepared the manuscript. E. S. F. supervised the data analyses and contributed to the manuscript writing. G. Z., E. S. F., J. T., C. L. and J. B. C. made critical revisions of the manuscript for important intellectual content. All authors contributed to and approved the final manuscript. All authors declare that there are no conflicts of interest. There are no sources of financial support.

\section{References}

1. Vestbo J (2004) Chronic bronchitis: should it worry us? Chron Respir Dis 1, 173-176.

2. Hayes D \& Meyer KC (2007) Acute exacerbations of chronic bronchitis in elderly patients: pathogenesis, diagnosis and management. Drugs Aging 24, 555-572.

3. Pelkonen M, Notkola IL, Nissinen A, et al. (2006) Thirty-year cumulative incidence of chronic bronchitis and COPD in relation to 30-year pulmonary function and 40-year mortality: a follow-up in middle-aged rural men. Chest $\mathbf{1 3 0}$, 1129-1137.

4. Vestbo J, Prescott E \& Lange P (1996) Association of chronic mucus hypersecretion with FEV1 decline and chronic obstructive pulmonary disease morbidity. Copenhagen City Heart Study Group. Am J Respir Crit Care Med 153, 1530-1535.

5. Fuhrman C, Roche N, Vergnenegre A, et al. (2009) Chronic bronchitis: prevalence and quality of life. Analysis of data from the French Health Interview Survey 2002-2003. Rev Mal Respir 26, 759-768.

6. Sin DD, Wu L \& Man SF (2005) The relationship between reduced lung function and cardiovascular mortality: a population-based study and a systematic review of the literature. Chest 127, 1952-1959.

7. Ekberg-Aronsson M, Lofdahl K, Nilsson JA, et al. (2008) Hospital admission rates among men and women with symptoms of chronic bronchitis and airflow limitation corresponding to the GOLD stages of chronic obstructive pulmonary disease - a population-based study. Respir Med 102, 109-120.

8. Baeke F, Etten EV, Overbergh L, et al. (2007) Vitamin $\mathrm{D}_{3}$ and the immune system: maintaining the balance in health and disease. Nutr Res Rev 20, 106-118.

9. Moro JR, Iwata M \& von Andriano UH (2008) Vitamin effects on the immune system: vitamins A and D take centre stage. Nat Rev Immunol 8, 685-698.

10. van EE, Stoffels K, Gysemans C, et al. (2008) Regulation of vitamin D homeostasis: implications for the immune system. Nutr Rev 66, S125-S134.

11. Provvedini DM, Tsoukas CD, Deftos LJ, et al. (1983) 1,25-Dihydroxyvitamin $\mathrm{D}_{3}$ receptors in human leukocytes. Science 221, 1181-1183.

12. Chishimba L, Thickett DR, Stockley RA, et al. (2010) The vitamin $\mathrm{D}$ axis in the lung: a key role for vitamin D-binding protein. Thorax 65, 456-462.

13. Hughes DA \& Norton R (2009) Vitamin D and respiratory health. Clin Exp Immunol 158, 20-25.

14. Liu PT, Stenger S, Li H, et al. (2006) Toll-like receptor triggering of a vitamin D-mediated human antimicrobial response. Science 311, 1770-1773.

15. Ginde AA, Mansbach JM \& Camargo CA (2009) Association between serum 25-hydroxyvitamin $\mathrm{D}$ level and upper respiratory tract infection in the Third National Health and Nutrition Examination Survey. Arch Intern Med 169, 384-390. 
16. Black PN \& Scragg R (2005) Relationship between serum 25-hydroxyvitamin $\mathrm{D}$ and pulmonary function in the Third National Health and Nutrition Examination Survey. Chest 128, 3792-3798.

17. Hagaman JT, Panos RJ, McCormack FX, et al. (2011) Vitamin $\mathrm{D}$ deficiency and reduced lung function in connective tissueassociated interstitial lung diseases. Chest 139, 353-360.

18. Li F, Peng M, Jiang L, et al. (2011) Vitamin D deficiency is associated with decreased lung function in Chinese adults with asthma. Respiration 81, 469-475.

19. Zosky GR, Berry LJ, Elliot JG, et al. (2011) Vitamin D deficiency causes deficits in lung function and alters lung structure. Am J Respir Crit Care Med 183, 1336-1343.

20. Brehm JM, Celedon JC, Soto-Quiros ME, et al. (2009) Serum vitamin D levels and markers of severity of childhood asthma in Costa Rica. Am J Respir Crit Care Med 179, $765-771$.

21. Brehm JM, Schuemann B, Fuhlbrigge AL, et al. (2010) Serum vitamin $\mathrm{D}$ levels and severe asthma exacerbations in the Childhood Asthma Management Program Study. J Allergy Clin Immunol 126, 52-58.

22. Kunisaki KM, Niewoehner DE, Singh RJ, et al. (2010) Vitamin D status and longitudinal lung function decline in the Lung Health Study. Eur Respir J 37, 238-243.

23. Shaheen SO, Jameson KA, Robinson SM, et al. (2011) Relationship of vitamin D status to adult lung function and COPD. Thorax 66, 692-698.

24. Centers for Disease Control and Prevention (2010) National Center for Health Statistics: National Health and Nutrition Examination Survey. http://www.cdc.gov/nchs/nhanes/ nhanes_questionnaires.htm (accessed December 2010).

25. Iversen L, Hannaford PC, Godden DJ, et al. (2007) Do people self-reporting information about chronic respiratory disease have corroborative evidence in their general practice medical records? A study of intermethod reliability. Prim Care Respir J 16, 162-168.

26. Holick MF \& Chen TC (2008) Vitamin D deficiency: a worldwide problem with health consequences. Am J Clin Nutr 87, S1080-S1086.

27. Janssens W, Lehouck A, Carremans C, et al. (2009) Vitamin D beyond bones in chronic obstructive pulmonary disease: time to act. Am J Respir Crit Care Med 179, 630-636.

28. Janssens W, Bouillon R, Claes B, et al. (2010) Vitamin D deficiency is highly prevalent in COPD and correlates with variants in the vitamin D-binding gene. Thorax 65, 215-220.

29. Miniño AM, Xu JQ \& Kochanek KD (2010) Deaths: Preliminary Data for 2008. National Vital Statistics Reports; vol. 59, no. 2. Hyattsville, MD: National Center for Health Statistics. http://www.cdc.gov/nchs/data/nvsr/nvsr59/nvsr59_02.pdf (accessed December 2010).

30. Sutherland ER, Goleva E, Jackson LP, et al. (2010) Vitamin D levels, lung function, and steroid response in adult asthma. Am J Respir Crit Care Med 181, 699-704.

31. Liu PT, Stenger S, Tang DH, et al. (2007) Cutting edge: vitamin D-mediated human antimicrobial activity against Mycobacterium tuberculosis is dependent on the induction of cathelicidin. I Immunol 179, 2060-2063.

32. Devereux G, Wilson A, Avenell A, et al. (2010) A casecontrol study of vitamin D status and asthma in adults. Allergy 65, 666-667.

33. Adams JS \& Hewison M (2008) Unexpected actions of vitamin $D$ : new perspectives on the regulation of innate and adaptive immunity. Nat Clin Pract Endocrinol Metab 4, 80-90.

34. Maruotti N \& Cantatore FP (2010) Vitamin D and the immune system. J Rheumatol 37, 491-495.

35. Fritsche J, Mondal K, Ehrnsperger A, et al. (2003) Regulation of 25-hydroxyvitamin $\mathrm{D}_{3}-1$ alpha-hydroxylase and production of 1 alpha,25-dihydroxyvitamin $\mathrm{D}_{3}$ by human dendritic cells. Blood 102, 3314-3316.

36. Monkawa T, Yoshida T, Hayashi M, et al. (2000) Identification of 25-hydroxyvitamin $\mathrm{D}_{3}$ 1alpha-hydroxylase gene expression in macrophages. Kidney Int 58, 559-568.

37. Rigby WF, Stacy $\mathrm{T} \&$ Fanger MW (1984) Inhibition of T lymphocyte mitogenesis by 1,25 -dihydroxyvitamin $\mathrm{D}_{3}$ (calcitriol). J Clin Invest 74, 1451-1455.

38. Tsoukas CD, Watry D, Escobar SS, et al. (1989) Inhibition of interleukin-1 production by 1,25-dihydroxyvitamin $\mathrm{D}_{3}$. J Clin Endocrinol Metab 69, 127-133.

39. Kanervisto M, Saarelainen S, Vasankari T, et al. (2010) COPD, chronic bronchitis and capacity for day-to-day activities: negative impact of illness on the health-related quality of life. Chron Respir Dis 7, 207-215.

40. Oh EG, Kim SH, Kim BH, et al. (2010) Health behaviour and quality of life in Korean adults with respiratory disease: National Health Survey, 2005. Int J Tuberc Lung Dis 14, $772-778$.

41. Looker AC, Lacher DA, Pfeiffer CM, et al. (2009) Data advisory with regard to NHANES serum 25-hydroxyvitamin D data. Am J Clin Nutr 90, 695.

42. Institute of Medicine of the National Academies (2010) Dietary Reference Intakes for Calcium and Vitamin D. Report Brief. http://www.iom.edu/ /media/Files/Report\%20Files/2010/ Dietary-Reference-Intakes-for-Calcium-and-Vitamin-D/ Vitamin\%20D\%20and\%20Calcium\%202010\%20Report\% 20Brief.pdf (accessed December 2010). 